\title{
COMPONENTS OF THE BUDGET SYSTEM OF UKRAINE AS FACTORS OF FINANCIAL AND ECONOMIC SECURITY
}

\author{
Oleh Holovko', Lilia Solomonova²
}

\begin{abstract}
The purpose of this study is to analyze the components of the budget system of Ukraine as factors of financial and economic security to identify negative trends in the context of the implementation of decentralization reform. It is proved that the research of this direction should start with the analysis of the conceptual apparatus and structural relationships between categories. At the top level of the hierarchy there is the category of national security of Ukraine, which, according to current legislation, means the protection of state sovereignty, constitutional order and other national interests of the country from real and potential threats. The category of financial and economic security is also often used in the scientific literature. Given the above classification, in this case we are talking about the financial security of the country as a factor of economic security. Methodology. To stimulate economic development, the practice of modern budget regulation provides for the presence of a planned deficit, which is a source of local and public debt. Depending on the areas of its financing, there are domestic and foreign, local and national debts. The relationship between the above indicators determines the level of budget security of the country, which is one of the most important factors of financial stability was identified in the work. Results. It is proved that, according to the results of the analysis, practical recommendations on budget policy of Ukraine as a factor of financial and economic security should take into account the following steps: against the background of growing social burden on the budget, it is necessary to continue the redistribution of budget funds in favour of the regions, which will increase their level of financial autonomy and reduce the amount of transfer payments; pursue a strict restriction policy to prevent the growth of the state budget deficit and uncontrolled increase in debt; the problem of pension provision increases the burden on the state budget every year. It is necessary to take measures to create a cumulative system of state and non-state pension insurance. Practical implications. The practical consequences prove that in 2016 the public debt of the consolidated budget of Ukraine reached a record $81 \%$ of GDP. However, effective economic and budgetary policy allowed to reduce it in 2019 to $50.3 \%$, which was positive. Moreover, the share of external debt was $29.2 \%$. The high budget deficit in 2020 will lead to an increase in debt to $58.7 \%$ of GDP, which offsets the previous positive changes. It is determined that at the beginning and at the end of the study period the expenditures of the pension system of Ukraine have been equal to about $10 \%$ of GDP. At the same time, financing from own revenues has decreased from $8 \%$ to $6 \%$, which is negative. The most critical situation became after 2013, when this indicator began to decline rapidly, increasing the burden on the state budget. Value/originality of the work is an analysis of the components of the budget system of Ukraine as factors of financial and economic security, which in contrast to the existing ones is based on the need for further implementation of decentralization reform and allows to develop practical recommendations for budget regulation.
\end{abstract}

Key words: financial and economic security, budget system, budget security, decentralization, budget regulation.

JEL Classification: E42, Q01

\section{Introduction}

At the beginning of the recession, issues related to the mechanisms of forming a strategy for ensuring the financial and economic security of the country are always gaining special relevance in research. In this context, security means the stability of

\footnotetext{
Corresponding author:

${ }^{1}$ Black Sea Research Institute of Economy and Innovation, Ukraine.

E-mail: o.p.golovko@gmail.com

ORCID: https://orcid.org/0000-0003-0841-4534

${ }^{2}$ Black Sea Research Institute of Economy and Innovation, Ukraine.
}

the dynamic system within acceptable limits. On the other hand, security means the ability of the economic system to withstand both external and internal negative manifestations.

Research in this area should begin with an analysis of the conceptual apparatus and structural 
relationships between categories. At the top level of the hierarchy is the category of national security of Ukraine, which, according to current legislation (On the national security of Ukraine), means the protection of state sovereignty, constitutional order and other national interests of the country from real and potential threats. Issues of national security risks have been studied by such scientists as: V. Bilous, A. Buteiko, Yu. Nikitin, O. Kostenko, H. Sytnyk and others (Nikitin, 2015).

Regarding the provision of sustainable socioeconomic development, these issues belong to the sphere of economic security (Lekar, 2012). V. Heiets, V. Honcharova, S. Lekar, V. Muntian, O. Skoruk, S. Shkarlet were engaged in the development of its essence, constituent elements and problems of public administration. Also, the issue of methodological assessment of the level of economic security of the state was paid attention at the legislative level (Methodical recommendations for calculating the level of economic security of Ukraine). According to the current methodological recommendations, it includes: production, demographic, energy, foreign economic, investment and innovation, macroeconomic, food, social, and financial security.

The category of financial and economic security is also often used in the scientific literature. Given the above classification, in this case we are talking about the financial security of the country as a factor of economic security. Its essence, evaluation methods and role, in the context of national interests, were studied in the works by $\mathrm{O}$. Baranovskyi, A. Kalantai, O. Melykh, A. Sukhorukov and others (Melykh, 2013: Kalantai, 2012). The purpose of the country's financial system includes monetary policy, stable functioning of the banking and nonbanking financial sectors, ensuring the financial stability of public finances on the basis of balanced revenues and expenditures of budgets at all levels and more.

Given the above, the purpose of this study is to analyze the components of the budget system of Ukraine, as factors of financial and economic security, to identify negative trends in the context of decentralization reform.

\section{Components of the budget system}

According to the decentralization reform, which has been actively implemented in the budget system of Ukraine from 2015 to the present day, the main components of the budget system are local budgets of amalgamated territorial communities of settlements, cities, regions and the State Budget. According to the Budget Code (Budget Code of Ukraine), their sources of income are tax and nontax revenues.

Among tax revenues, local budget revenues do not include import duties and value added tax. However, they have revenues from local taxes and fees that do not belong to the State budget. We have a similar situation with non-tax revenues from the NBU, which can be included only in the State budget revenues.

The goal of local self-government is the development of regions and common social standards of living throughout Ukraine. This goal is achieved by generally accepted standards of budget security per 1 person living in a particular region. On the other hand, the volume and structure of expenditures of the State Budget of Ukraine are determined by the socio-economic development strategy adopted at the state level.

The absolute difference between expenditures and revenues of budgets of all levels determines the volume of their deficit or surplus. In relative terms, at the local level, the absolute difference obtained is compared with the value of gross regional product, at the state level - with the volume of gross domestic product and so on.

Given that each region has its own unique natural and climatic conditions of existence, structure and location of productive forces and the level of economic development, they differ significantly in terms of budget revenues. This means that today most regions do not have the opportunity to provide the necessary level of social living standards at their own expense.

In order to territorially equalize the uneven development and cover part of the deficit of local budgets, intergovernmental transfers are transferred from them to the State Budget free of charge and irrevocably. In their economic essence, they are equalization grants.

\section{Indicators of budget regulation efficiency}

To stimulate economic development, the practice of modern budget regulation provides for the presence of a planned deficit, which is a source of local and public debt. Depending on the areas of its financing, there are domestic and foreign, local and national debts.

The ratio between the above indicators determines the level of budget security of the 
country, which is one of the most important factors of financial stability. Table 1 shows the results of calculations of indicators of efficiency of budget regulation according to the data of 2004-2019.

The decentralization reform provides for greater financial autonomy for the regions to be able to solve socio-economic problems on the ground. Column (2) Table 1 shows that from 2004 to 2014 the volume of revenues to local budgets in relative terms had a chaotic dynamics. During 2015-2019, their share in the country's GDP had a steady upward trend and increased from $6.1 \%$ to $7.6 \%$.

The share of local budget expenditures provided by transfers from the State Budget of Ukraine in 2015 was a record $59.1 \%$. Already in 2019, this figure decreased to $46.4 \%$. Thus, it can be stated that the system of public financial management is gradually undergoing changes aimed at developing the autonomy of the regions. However, the financial dependence of local communities on the center today remains quite high and needs further changes in this direction.

From the point of view of budget security, the data for the third quarters of 2020 need special attention. Here the volume of revenues to local budgets amounted to $7.8 \%$ of GDP. At the same time, intergovernmental transfers were only $3.9 \%$, which is much less than in previous years, according to column (3) of Table 1. This indicates a saving of money by the central government and the need to reduce costs on the ground.

Despite the inefficiency of public administration, Ukraine remains one of the leaders among Western European countries in terms of the influence of the public sector on the redistribution of GDP, according to column (4) of Table 1 . As we can see, over the last decade, government consolidated budget expenditures have remained almost unchanged at about $34-35 \%$ of GDP. With an aging population and increased spending on social and pension benefits, this indicator will tend to grow. That is why, at this stage it is extremely important: - firstly, to prevent the growing role of state regulation in the distribution of public product; - secondly, to continue the transfer of powers and financial resources to local communities, in accordance with the decentralization reform.

The stimulating role of the budget deficit is that the return on the efficient use of borrowed funds may exceed the cost of raising them. That is why the dynamics of this indicator is given in column (5). In world practice, the acceptable level of budget deficit is $2-3 \%$ of GDP. As you can see, in 2015-2019, Ukraine almost met these restrictions. However, in 2020, the consolidated budget deficit was equal to the highest level since 2004 at $8.4 \%$. Inefficient use of borrowed funds leads to the problem of public debt, the dynamics of which is shown in Figure 1.

Table 1

Indicators of budget regulation efficiency in Ukraine according to the data of 2004-2019

\begin{tabular}{|c|c|c|c|c|}
\hline Year & $\begin{array}{c}\text { Volume of revenues to } \\
\text { local budgets, \% of GDP }\end{array}$ & $\begin{array}{c}\text { Volume of transfers from } \\
\text { the state budget to the } \\
\text { local budget, \% of GDP }\end{array}$ & $\begin{array}{c}\text { The level of redistribution } \\
\text { of GDP through the } \\
\text { consolidated budget, } \%\end{array}$ & $\begin{array}{c}\text { Consolidated budget } \\
\text { deficit, \% of GDP }\end{array}$ \\
\hline 1 & 2 & 3 & $29.3 \%$ & 5 \\
\hline 2004 & $5.9 \%$ & $4.9 \%$ & $32.1 \%$ & $1.8 \%$ \\
\hline 2005 & $6.2 \%$ & $5.3 \%$ & $32.2 \%$ & $0.7 \%$ \\
\hline 2006 & $6.8 \%$ & $6.3 \%$ & $31.4 \%$ & $1.1 \%$ \\
\hline 2007 & $7.6 \%$ & $6.2 \%$ & $32.6 \%$ & $2.4 \%$ \\
\hline 2008 & $7.1 \%$ & $6.2 \%$ & $33.6 \%$ & $6.0 \%$ \\
\hline 2009 & $6.9 \%$ & $6.8 \%$ & $34.9 \%$ & $1.8 \%$ \\
\hline 2010 & $6.6 \%$ & $7.2 \%$ & $31.7 \%$ & $3.6 \%$ \\
\hline 2011 & $5.8 \%$ & $7.2 \%$ & $35.0 \%$ & $4.4 \%$ \\
\hline 2012 & $6.3 \%$ & $8.8 \%$ & $34.8 \%$ & $4.6 \%$ \\
\hline 2013 & $6.3 \%$ & $8.0 \%$ & $33.4 \%$ & $1.6 \%$ \\
\hline 2014 & $5.7 \%$ & $8.3 \%$ & $34.3 \%$ & $2.3 \%$ \\
\hline 2015 & $6.1 \%$ & $8.8 \%$ & $35.1 \%$ & $1.4 \%$ \\
\hline 2016 & $7.2 \%$ & $6.3 \%$ & $35.4 \%$ & $3.9 \%$ \\
\hline 2017 & $7.7 \%$ & $9.1 \%$ & $35.1 \%$ & $2.1 \%$ \\
\hline 2018 & $7.4 \%$ & $8.6 \%$ & $34.5 \%$ & \\
\hline 2019 & $7.6 \%$ & $6.6 \%$ & & \\
\hline
\end{tabular}




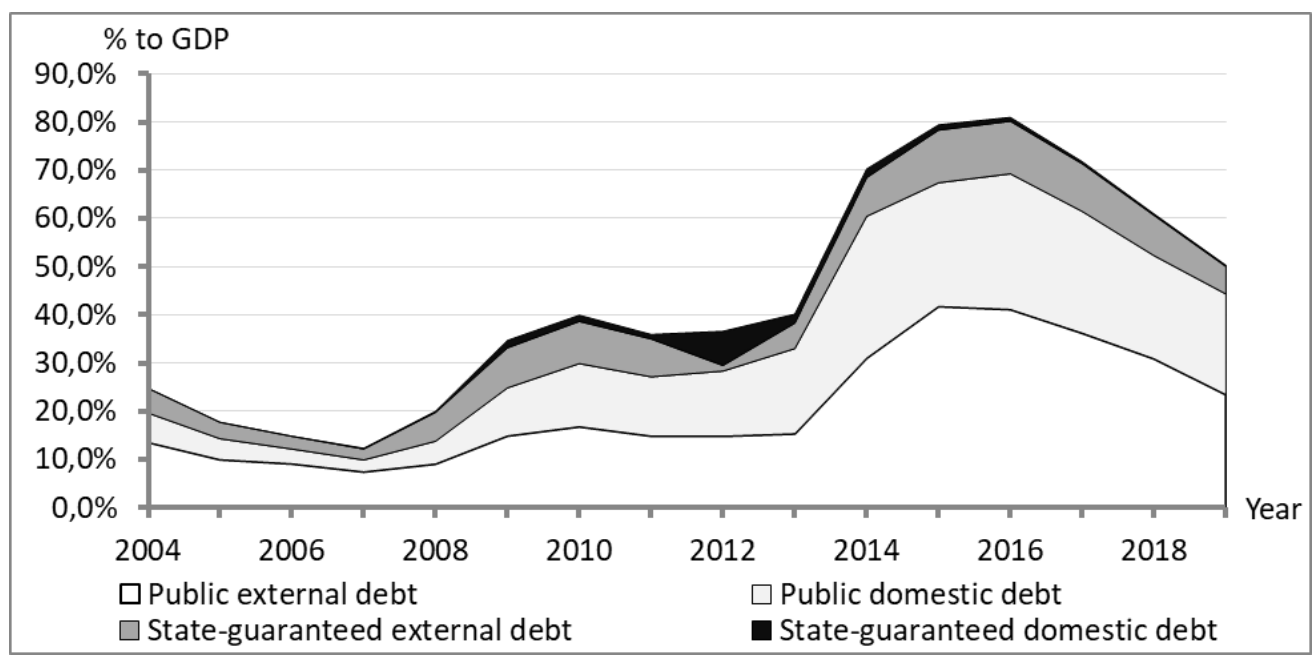

Figure 1. Dynamics of public debt for 2004-2019 in \% of gross domestic product

As can be seen from Figure 1, in 2016, the public debt of the consolidated budget of Ukraine reached a record $81 \%$ of GDP. However, effective economic and budgetary policy allowed to reduce it in 2019 to 50.3\%, which was positive. Moreover, the share of external debt was $29.2 \%$. The high budget deficit in 2020 will lead to an increase in debt to $58.7 \%$ of GDP, which offsets the previous positive changes.

\section{Consideration of the budget of the pension fund}

Consideration of the budget of the pension fund needs special attention, as a significant part of the State budget expenditures each year is used to cover its deficit.

Prolongation of working age is a forced measure associated with a gradual increase in life expectancy. Thus, according to WHO, in Ukraine it is 72.5 years. Of these, for men -67.6 years, for women -77.1 years and so on.

On the other hand, the constant growth of the actual subsistence level and the need to adjust the average level of pension provision per capita increased the burden on the pension fund. Thus, in the prices of June 2020, the actual subsistence level was 3,974 UAH.

The consequence of these trends is the formation of a budget deficit of the pension fund. Thus, according to 2019, the share of own revenues in its total expenditures was only $55.7 \%$. The main source of financing the deficit is the State Budget of Ukraine. The dynamics of these indicators for 2004-2019 in graphical form is shown in Figure 2.
In order to exclude the inflation factor, bringing the total expenditures to the prices of the base year allowed us to calculate the average annual growth rate of this indicator, which was equal to $+4.1 \%$. In fact, this means that real pension insurance payments, in comparable prices, increased from 2004 to 2019 by 1.8 times. At the same time, the pension fund's own income increased on average by $+1.8 \%$ annually, or 1.3 times over the entire period.

This increase in the deficit was offset by the state budget, the share of which in the total expenditures of the pension fund during the study period increased from $16.5 \%$ to $44.1 \%$ and in 2019 amounted to 182,270 million UAH.

Preservation of these trends in the future carries significant risks in ensuring the financial and economic security of the state. To confirm this, it should be noted that pension expenditures are the most important item of state budget expenditures. In recent years, their share has ranged from $22 \%$ to $30 \%$. That is why one of the conditions for the stability of such a system is economic growth at a faster pace, which will maintain this ratio.

To this end, we have built a graph of the dynamics of expenditures of the pension fund by source of income, in \% of gross domestic product, Figure 3.

As you can see, at the beginning and the end of the study period, the expenditures of the pension system of Ukraine were about $10 \%$ of GDP. At the same time, financing from own revenues decreased from $8 \%$ to $6 \%$, which was negative. The most critical situation became after 2013, when this indicator began to decline rapidly, increasing the burden on the state budget. 


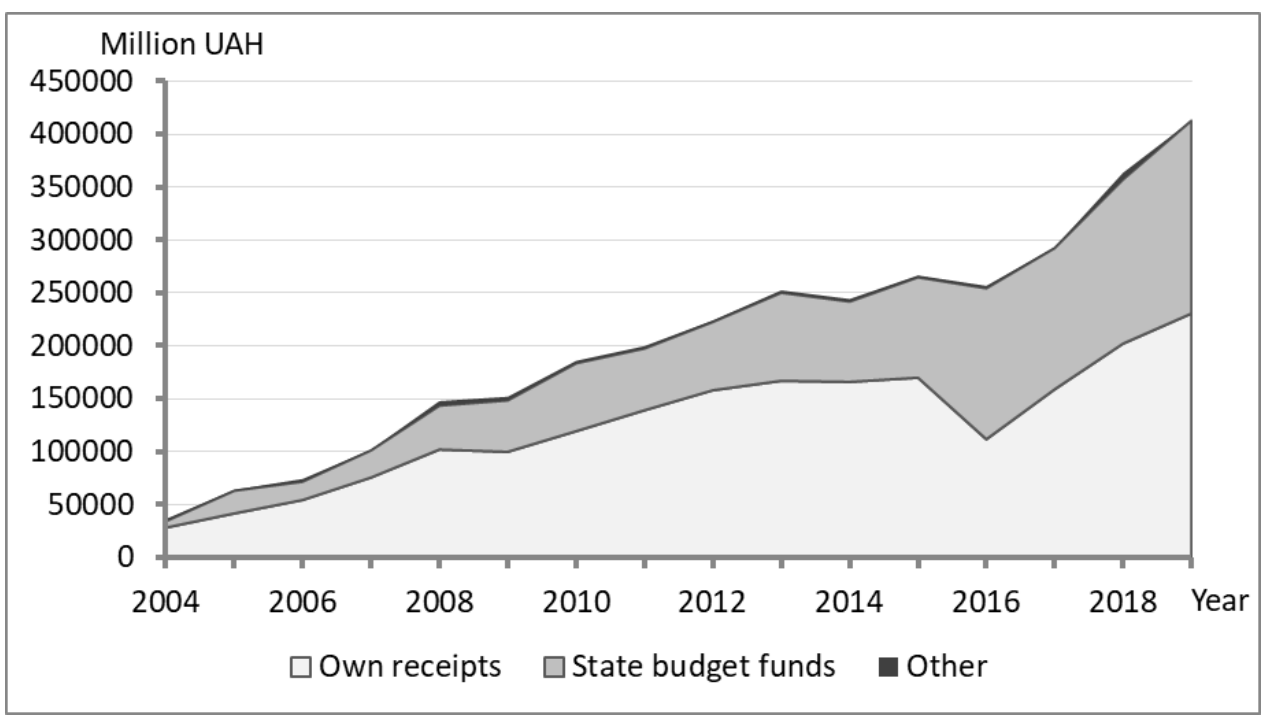

Figure 2. Dynamics of pension fund expenditures for 2004-2019 in actual prices each year

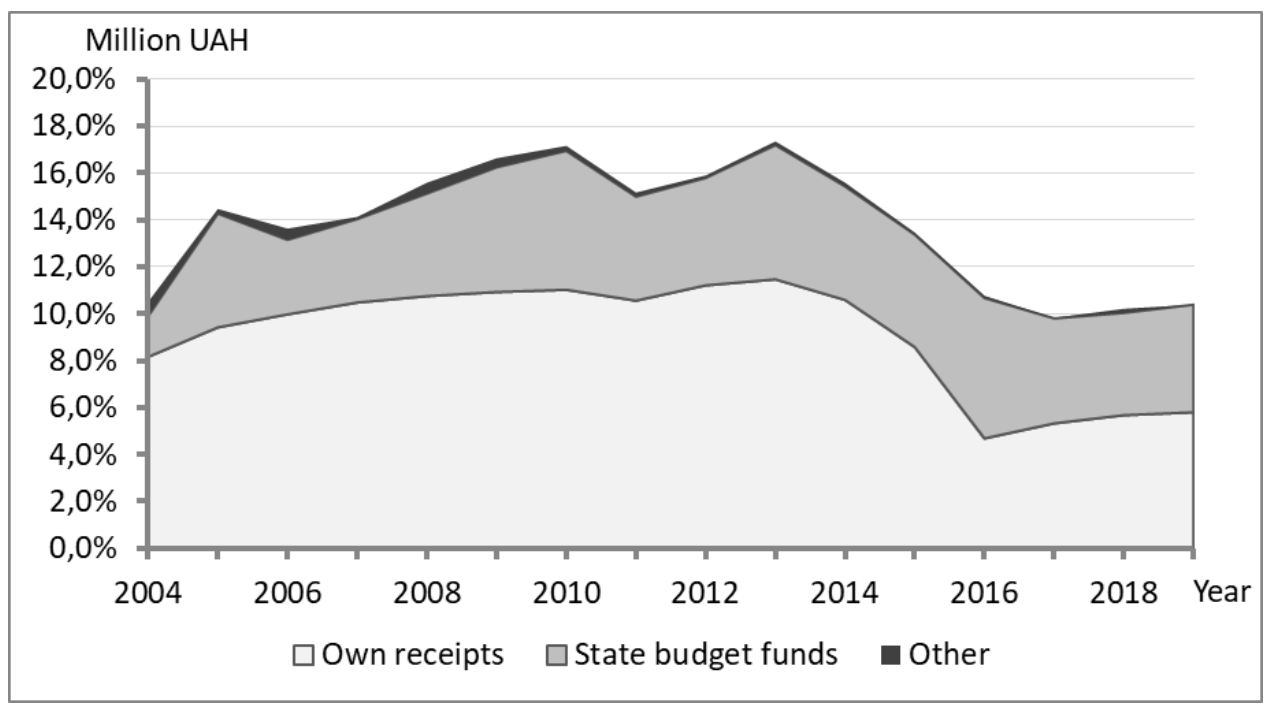

Figure 3. Dynamics of pension fund expenditures for 2004-2019 in \% of gross domestic product

Summarizing the above, the problem of pension provision is directly related to the stability of the budget system of Ukraine as a factor of financial and economic security.

It can be stated that the possibilities of the pension system of Ukraine of the first level, on the principles of joint and several compulsory pension insurance, have completely exhausted themselves to date. That is why the urgent issue is the introduction of the second and third levels as soon as possible, which provide for the creation of a cumulative system of state and non-state pension insurance. On the other hand, accelerating economic growth can significantly reduce the burden on the state budget.

\section{Conclusions}

Thus, according to the results of the analysis, practical recommendations on the budget policy of Ukraine, as a factor of financial and economic security, should take into account the following steps:

1. Against the background of increasing social burden on the budget, it is necessary to maintain the level of state redistribution of gross domestic product at the expense of its expenditures.

2. It is necessary to continue the redistribution of budget funds in favour of the regions, which will increase their level of financial autonomy and reduce the amount of transfer payments. 
3. To pursue a strict restrictive policy to prevent the growth of the State budget deficit and uncontrolled increase in debt.

4. The problem of pension provision increases the burden on the State budget every year. It is necessary to take measures to create a cumulative system of state and non-state pension insurance.

Economic growth will help to mitigate these budget problems and their impact on the country's financial security; recession will exacerbate them.

Thus, the scientific novelty of this work is the analysis of the components of the budget system of Ukraine as factors of financial and economic security, which in contrast to the existing ones proceeds from the need for further implementation of decentralization reform and allows to develop practical recommendations for budget regulation.

\section{References:}

On the national security of Ukraine: Law of Ukraine of June 21, 2018 № 2469-VIII / The Verkhovna Rada of Ukraine. Available at: http://nbuv.gov.ua/UJRN/jnn_2015_2_19

Nikitin, Yu. V. (2015). National security of Ukraine in modern conditions: risks and factors of influence. Juridical science, vol.2, pp. 141-147. Available at: http://nbuv.gov.ua/UJRN/jnn_2015_2_19

Lekar, S. I. (2012). The concept and content of economic security. Forum prava, vol. 2, pp. 399-402. Available at: http://nbuv.gov.ua/UJRN/FP_index.htm_2012_2_62

Methodical recommendations for calculating the level of economic security of Ukraine: Order of the Ministry of Economic Development and Trade of Ukraine dated 29.10.2013 № 1277. Available at: https://zakon.rada.gov.ua/rada/show/v1277731-13

Melykh, O. (2013). Financial security of the state: essence, evaluation criteria and preventive measures of strengthening. Economic analysis, vol. 12(2), pp. 266-272. Available at: http://nbuv.gov.ua/UJRN/ ecan_2013_12\%282\% 29_54

Kalantai, A. M. (2012). The role and place of financial security in the context of national interests. Collection of scientific works of the National University of the State Tax Service of Ukraine, vol. 1, pp. 143-153. Available at: http://nbuv.gov.ua/UJRN/znpnudps_2012_1_17

Budget Code of Ukraine. № 2456-VI, dated 08.07.2010 with changes and additions. Available at: https://zakon.rada.gov.ua/laws/show/2456-17 